\title{
Szétfejlődés vagy útfüggőség? Trianon hatásai a fejlettség földrajzi különbségeire a történeti Esztergom és Komárom vármegyék területén
}

\section{Diverging or dependent development? The impacts of the Treaty of Trianon on spatial development patterns in the territory of Esztergom and Komárom counties}

\author{
MIKLE GYÖRGY
}

\begin{abstract}
MIKLE György: tudományos munkatárs, ELKH Bölcsészettudományi Kutatóközpont, Történettudományi Intézet; 1097 Budapest, Tóth Kálmán u. 4.; mikle.gyorgy@abtk.hu; https://orcid.org/0000-0001-8490-6165
\end{abstract}

KULCSSZAVAK: területi fejlettség; Trianon; történeti földrajz

ABSZTRAKT: Tanulmányomban a történeti Esztergom és Komárom vármegyék területi különbségeinek 1910 és 1941 között lezajlott változásait vizsgáltam települési léptéken, a történeti földrajz kvantitatív módszerei segítségével. A terület Duna bal partján található részén 1920 és 1938 között a csehszlovák állam szándékai alakították a helyi társadalmak életkörülményeit. Ezen a területen fontos esemény volt a csehszlovák földosztás, amely egyben az utódállam nemzetiségi politikájának részét is képezte, ezért kiemelt figyelmet szenteltem a földműves népesség helyzetének, a birtokviszonyok alakulásának. Az 1910-re és 1938/1941-re elvégzett számítások eredményei azt mutatják, hogy a korszakban a fejlettség komplex mutatói elsősorban a népesség foglalkozási szektorok szerinti megoszlása mentén differenciálódtak, így a tartósan fejlett területek a történeti vármegyék bányászati tevékenységet folytató települései, valamint a városok voltak. Míg az első világháború előtt a fejlettségi rangsor végén zömmel a Duna bal partján fekvő települések álltak, addig az első (1919 és 1938 közötti) csehszlovák korszak végére ezeken a területeken több település is előbbre lépett a rangsorban. Ezek főleg olyan települések, ahol az első világháború előtt a mezőgazdasági keresők több mint kétharmada cseléd, vagy mezőgazdasági munkás volt, az első bécsi döntés idejére azonban arányuk 50\% környékére, vagy az alá csökkent. Mindeközben a vizsgált területen belül a történeti Komárom vármegye északkeleti része, valamint Kelet-Csallóköz és a vármegye déli része tartósan alacsonyabb fejlettségű területnek számított. Ennek alapján az elemzett három évtizedben nem beszélhetünk a terület Duna bal és jobb partján fekvő településeinek szétfejlődéséről, hiszen sokkal erősebb volt a népesség foglalkozási megoszlása által meghatározott útfüggőség, amely inkább egy keleti-nyugati kettősséggel jellemezhető.

György MIKLE: research fellow, Institute of History, ELKH Research Centre for the Humanities; Tóth Kálmán u. 4., H-1094 Budapest, Hungary; mikle.gyorgy@abtk.hu; https://orcid.org/00000001-8490-6165

KEYWORDS: regional development disparities; Treaty of Trianon; historical geography

ABSTRACT: This study investigates the transformation of territorial development disparities in Esztergom and Komárom counties between 1910 and 1941. The area investigated belonged to Hungary before WWI, but over half of its settlements were given to Czechoslovakia in 1919, as the

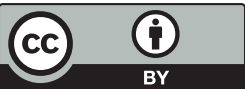


river Danube constituted the new state border up until 1938. Before the world war, large agricultural estates were important actors at both sides of the river with a remarkable size of agricultural land, and consequently a great proportion of agricultural earners worked as servants or agricultural workers at these estates. However, a rather radical land reform began in Czechoslovakia in 1919, which aimed to dissolve many of the large estates and promoted agricultural smallholders, predominantly those belonging to the Czech and Slovak ethnicities. Meanwhile in Hungary the agricultural land concentration hardly changed, although the number of smallholders grew after a conservative land reform was carried out in 1920.

The study scrutinizes the ways (1) development disparities in the territory of Esztergom and Komárom counties changed after the Treaty of Trianon, and (2) agricultural and ethnic policies affected local development patterns. In order to answer these questions, a multi-dimensional development index was applied for 1910 (for both sides of the Danube), 1938 (for the left side of the Danube, belonging to Czechoslovakia) and 1941 (for the right side of the Danube, belonging to Hungary). Besides the development index, proportion of agricultural land owners and leaseholders was analysed in order to shed light on the role of land concentration on local development.

The results indicate that territories characterised by non-agricultural population (villages inhabited by miners, and a couple of major towns) were among the most developed ones both before and after Trianon. These settlements were located predominantly on the right side of river Danube. Between 1910 and 1938/1941 a number of settlements on the left side of river Danube stepped forward in terms of development ranking: at the eastern part of this area a number of villages were above the average development level in 1938. These settlements were affected by the Czechoslovak land reform, hence the proportion of land owners and agricultural leaseholders grew between 1910 and 1938. On the other hand, the western territories of the area investigated (at both sides of the Danube) can be characterised by diminishing development ranks: these villages were still inhabited predominantly by the agricultural proletariat in 1938/1941.

\section{Bevezetés}

Közismert tény, hogy az 1920-as trianoni döntéssel meghúzott államhatárok több területen is korábban - társadalmi és gazdasági kapcsolataik révén - szervesen összekapcsolódó térségeket választottak ketté. Ezeken a területeken a 20. század második felére gyakran módosultak a korábban kialakult struktúrák: a nemzetiségi összetételen túl a térségek jövedelmi helyzete, a gazdasági termelés szerkezete, közlekedési elérhetősége is megváltozott az utódállamokhoz került részeken és a Magyarországon maradt területeken egyaránt.

Az első világháború előtt több olyan városi vonzáskörzet is létezett, amelyet a határmegvonás kettévágott (Kovács 1990). Az egyik ilyen, számos szempontból koherensnek tekinthető térség az egykori Komárom vármegye, valamint Esztergom vármegye területe, ahol (bár a Duna jelenléte miatt a helyi társadalmak kapcsolatai némileg korlátozottak voltak) a határmegvonás elválasztotta a vármegyeszékhelyeket és vonzáskörzetüket (Esztergom esetén lásd Jaschitz 2010). Ezen felül több nagybirtok, uradalom integrálta a mezőgazdasági népesség jelentős részét, amelyek 1918 után komolyabb földterületet veszítettek el. Az ország területi vesztesége mellett fontos fejlemény volt az 1919-1920-as csehszlovák földreform is. Ezek a folyamatok megváltoztatták a lakosság többségének korábbi életkörülményeit és életvitelét, megélhetési stratégiáit, boldogulási útjait. 1938-ban 
a vármegyék nagy része néhány évre ismét Magyarországhoz került, ezt követöen a magyar állam az 1919-ben kezdődő csehszlovák földreformot is felülvizsgálta (Simon 2014; Tilkovszky 1964).

Tanulmányom tárgya e változások vizsgálata a történeti földrajz kvantitatív eszköztárának segítségével. A kérdéseim, hogy (1) miként módosultak a fejlettségre utaló társadalmi mutatószámok az 1910 és 1941 közötti időszakban a határ két oldalán, és (2) a birtok- és nemzetiségpolitikai döntések hogyan függnek össze az életszínvonallal. A korábbi, kapcsolódó kutatások (Demeter 2019) kimutatták, hogy a 20. század elején a vármegyék területén nagyjából azonos életszínvonal volt mérhető a Duna két partján, napjainkban viszont a Magyarországon maradt terület kedvezőbbnek tekinthető helyzetben van, mint a Kelet-Csallóköz és Párkány térsége. Ebből kiindulva kísérletet teszek annak felvázolására, hogy ez a hosszú távú szétfejlődés mennyiben ered az első (1919 és 1938 közötti) csehszlovák korszak folyamataiból, illetve megfordítva a kérdést, mennyire jellemezte a térséget (a korábban kialakult társadalmi és gazdasági szerkezet által meghatározott) útfüggőség a két világháború közötti időszakban.

Ezeket a kérdéseket kvantitatív módszerekkel vizsgálom, amelynek lehetőségeit és korlátait a következő fejezetben elemzem. A kutatás során használt adatbázis települési léptéken vizsgálódik, de a járási léptékre, valamint a Duna két partjára vonatkozóan is felvázolom a legfontosabb jellemzőket. Munkámmal egyrészt a történeti földrajzi vizsgálatok vonatkozó eredményeihez, a kvantitatív eszköztár felhasználási lehetőségeinek kérdésköréhez szeretnék adalékot szolgáltatni. Ezen túlmenően tanulmányom a jelenlegi állapotok jobb megértését szolgálja, mivel reményeim szerint közelebb vihet olyan összefüggések feltárásához, amelyek megvilágítják a napjainkra kialakult területi különbségek történeti hátterét.

\section{Elmélet és módszertan}

Munkám elméleti és módszertani keretezése három témakör rövid áttekintését kívánja meg.

1) A történeti földrajzi vizsgálatokon belül tanulmányom nem tekinthető a jelenlegi nemzetközi fősodorba illeszkedő munkának. A kvantitatív forradalom bázisán kialakuló, pozitivista közelítésmód ugyanis az 1970-es évek óta visszaszorulóban van az angolszász történeti földrajzban, és ez jellemzi a földrajztudomány nemzetközi trendjeit is. A közel ötven évvel ezelőtt jelentkező humanisztikus fordulat, majd az 1980-as évek végétől a posztmodern és posztstrukturalista közelítésmódok megjelenése a történeti földrajz módszertani bázisát és a vizsgált kérdések körét is megváltoztatta (Heffernan 2009). A 2000-es évekre ugyanakkor megjelentek olyan, GIS-re (Geographic Information System) építő tanulmányok is, amelyek a korábbi évtizedek társadalomelméleti bázisát integrálják, közelítésmódjukra a kritikai szemléletmód jellemzo, így ezek a munkák kulcsszerepet töl- 
tenek be a kvantitatív tudományosság megújításában (Offen 2013). Mivel az általam vizsgált földrajzi terület rurális vonásokkal jellemezhető, ezért tanulmányom a vidékföldrajz területéhez is kapcsolódik. Az angolszász történeti földrajzhoz hasonlóan, a vidékkutatásokban is a fent bemutatott paradigmaváltások játszódtak le (Kovách 2012; Woods 2005, 2009). Az általam elvégzett elemzés azonban elsősorban az 1980-as évek előtt domináns pozitivista vidékföldrajzhoz kötődik.

2) A trianoni döntés, a határváltozás hatásainak elemzésére korábban több szerző is vállalkozott, a témakörben a Csehszlovákiához került területekre fókuszáló írások is fellelhetők. A két világháború közötti időszakban a statisztika (Konkoly-Thege 1939; Thirring 1939) képviselői elsősorban a döntés igazságtalanságát, a területen élő magyarság által elszenvedett sérelmeket hangsúlyozták. A korszakban megjelent munkákban visszatérő elem a csehszlovák földreform aránytalanságának, a magyar anyanyelvű parasztságot ért hátrányok kiemelése (Haltenberger 2002; Hantos 2002). Az ezredforduló óta a csehszlovákiai magyarság helyzetét gazdaságtörténeti szemszögből is elemezték (lásd Gaucsík 2004), a közelmúltban megjelent tanulmányokban a határváltozás általánosabb gazdasági hatásai is terítékre kerültek (Tomka 2018). Jelentősnek tekinthető továbbá a trianoni határmegvonás területi fejlettségre gyakorolt hatásainak vizsgálata; a kérdéskörről született kvantitatív elemzések azonban már a következő témakörhöz kapcsolódnak.

3) Tanulmányom megközelítésmódja szorosan kapcsolódik a területi különbségek, a területi, települési fejlettség méréséhez és elemzéséhez. E kérdések vizsgálata a társadalomföldrajzban és a regionális tudományban gazdag irodalommal rendelkezik: a kvantitatív forradalom hatására a geográfiában az 1960-as évek közepétől (Berry 1964) jelentkező szemléletmód a vidéki térségek kutatásában is megjelent (Woods 2005). Az olyan sokdimenziós jellemzők, mint a fejlettség mérése a területi kutatások módszertani eszköztárában kiemelt helyet foglal el (Nemes Nagy 2005). A sokdimenziós fejlettségi mutatókat a földrajzosok olyan kérdések tárgyalásában is segítségül hívták, mint amilyen az alacsony fejlettségü, periferikus területek lehatárolása, illetve a módszer használhatósága a fejlesztéspolitikában (Jeney, Varga 2016; Pénzes, Demeter 2021). A fejlettséget kifejező komplex mutatók közül komolyabb figyelmet kapott az emberi jólét dimenzióit tömörítő HDI (Human Development Index, amely az egészség, a műveltség, valamint a jövedelem mérésére fókuszál), és az ennek mintájára létrehozott mutatószámok használata. A hazai elemzésekben települési szinten többek között Malatyinszky Szilárd (2010) tett kísérletet a HDI-hez hasonló mutató kidolgozására. A történeti vizsgálatokban, a 20. század elejére fókuszáló írások közül kiemelhető Szilágyi Zsolt (2018a) munkája, aki a HDI-hez tartalmában a lehető legközelebb álló mutatószámot dolgozott ki. Szilágyi (2018a) kiemelte, hogy a történeti vizsgálatok esetében a HDI három komponense közül a jövedelmet kifejező összetevő megtalálása a legnehezebb.

A területi egyenlőtlenségek történeti alakulását komplex mutatókkal vizsgáló szerzők közül többen vállalkoztak olyan mutatószámok kidolgozására, ame- 
lyek a HDI logikáján alapulnak, ám tartalmukban eltérnek ettől a mutatótól (lásd Beluszky 2000; Demeter, Szulovszky 2018). Ennek oka részben a rendelkezésre álló adatok hiánya, részben pedig az, hogy az életszínvonal alakulását kifejező dimenziók történetileg változónak tekinthetők. Az általam használt területi adatbázis és a komplex mutatók kidolgozásában jelentős támpontot nyújtottak azok az ezredforduló utáni munkák, amelyek a hazai területi különbségek történetének, időbeli változásának modellezésére vállalkoztak. A történeti országterület 20. század eleji helyzetével foglalkozó tanulmányok (Demeter, Szulovszky 2018) számos módszertani tanulsággal szolgáltak, illetve eredményeik fontos viszonyítási pontot jelentettek. A területi fejlettség jelenlegi országterületen mérhető évszázados folyamatait is többen vizsgálták a HDI-hez hasonló komplex mutatók segítségével.

A vármegyék szintjén végzett vizsgálatot Beluszky Pál (2000), aki 12 modernizációs elem területi képét elemezte. Bár írásának célja a modernizáció szintjének mérése volt, az általa szemlézett mutatók a későbbi fejlettségi vizsgálatokban is rendre felbukkantak; emellett a modernizáció területi mintázata is jelentős átfedést mutat a későbbi vizsgálatokban megjelenő fejlettségi mutatók alapján felvázolt képpel. Ezek között a munkák között említhető Győri és Mikle (2017) tanulmánya, akik járási léptékben elemezték a fejlettség hosszú időtávú változását. Írásukban a 20. század elejének fejlettségi viszonyait egy négy komponensből álló komplex mutatóval jellemezték (az írni-olvasni tudók aránya a 6 éven felüli népességből; az elhunytak közül a haláluk előtt orvosi kezelésben részesültek aránya; a kő- vagy téglaépítésű, illetve kő- vagy téglaalapozású lakóházak aránya; a nem mezőgazdasági foglalkozásúak aránya a keresők között). Pénzes János (2020) ehhez nagyban hasonló, ugyanakkor a jövedelmi viszonyokat erőteljesebben hangsúlyozó mutatószámot vezetett be a határ menti területek fejlettségének mérésére. A 20. század elejére Pénzes a csecsemőhalandóságot, a keresők és eltartottak arányát, az ipari keresők arányát, az egy főre jutó kataszteri tiszta jövedelmet, az egy főre jutó állami adóterhet, valamint az egy före jutó települési bevételt vonta össze komplex mutató formájában.

A határváltozások hosszú távú következményeinek kvantitatív vizsgálata ugyancsak több tanulmányban felbukkant, így például a Dunántúl nyugati részének Magyarországon maradt és Ausztriához került részeinek szétfejlődése (Győri, Jankó 2009), valamint az 1938 után Magyarországhoz visszacsatolt területek helyzetének elemzése (Demeter 2019) nem csupán módszertani szempontból, de a feltett kérdések tekintetében is olyan munkák, amelyek jelen tanulmány megírását inspirálták. Az előbbi munkában (Győri, Jankó 2009) a 20. század elején mérhető fejlettség komplex mutatójába a következő mutatók kerültek: az írni-olvasni tudók aránya a 6 éven felüli népességből; a kő- vagy téglaépítésű, illetve kő- vagy téglaalapozású lakóházak aránya; a keresők közül a nem mezőgazdasági foglalkozásúak aránya; a haláluk előtt orvosi kezelésben részesült elhunytak aránya; a vándorlási egyenleg rátája (1901-1910), valamint az egy mezőgazdasági keresőre eső kataszteri tiszta jövedelem. Demeter (2019) ugyanakkor egy jóval bővebb, 
27 indikátor aggregálásával előállított mutató alapján mutatta ki a 20. század eleji országterület fejlettségi különbségeit.

Ezekre a szakirodalmi eredményekre építve tanulmányomban olyan mutatószámokat alkalmazok, amelyek lehetővé teszik az egykori Esztergom és Komárom vármegyék fejlettségének települési szintű elemzését 1910 és 1941 között. A mutatókat az egyes időpontokra elérhető adatok köre alakítja, aminek következtében három különböző adatfelvétel alapján, tartalmilag két különböző fejlettségi mutatót fogok használni.

Az 1910-es népszámlálás adatai lehetővé teszik a vizsgált terület egészére egy olyan komplex mutató kidolgozását, amely a következő mutatószámokat foglalja magában: ${ }^{1}$

- az írni-olvasni tudók aránya a 6 éven felüli népességből (1910),

- a nem mezőgazdasági foglalkozásúak aránya a keresők közül (1910),

- a mezőgazdasági keresőkön belül az önálló birtokosok és bérlők aránya (1910),

- a jó minőségű (kő- vagy téglaépítésű, illetve kő- vagy téglaalapozású) lakóházak aránya (1910),

- a haláluk előtt orvosi kezelésben részesült elhunytak aránya (1901-1910).

A Trianon utáni helyzet felméréséhez az elérhető magyar adatfelvételekre támaszkodtam. Ezek közül az első az 1938-as felvidéki nép-, földbirtok- és állatösszeírás, amely az első bécsi döntés értelmében Magyarországhoz csatolt településeken zajlott. A felmérés alapján a következő fejlettségi mutató alkotható meg, amely tartalmában az 1910-eshez a lehető legközelebb áll:²

- az írni-olvasni tudók aránya a 6 éven felüli népességből (1938),

- a nem mezőgazdasági foglalkozásúak aránya a keresők közül (1938),

- a mezőgazdasági keresőkön belül az önálló birtokosok és bérlők aránya (1938),

- a népességszám-változás rátája (1910-1938;1910=100\%),

- az egy főre jutó lakóházak rátája (laksűrűség) (1938).

A másik adatfelvétel az 1941-es népszámlálás, amely ugyan a visszacsatolt területekre (így Esztergom és Komárom vármegyék Duna bal partján található településeire) is kiterjedt, az eredmények kötetbe rendezése és kiadása azonban többször elakadt, és mindmáig csak részlegesen valósult meg. Ennek következtében az 1941-es időmetszet az 1938-as mellé rendelve használható fel a Dunától délre eső települések fejlettségének mérésére. Erre az időpontra az 1938-assal egyező tartalommal alakítható ki a fejlettséget kifejező komplex mutató: ${ }^{3}$

- az írni-olvasni tudók aránya a 6 éven felüli népességből (1941),

- a nem mezőgazdasági foglalkozásúak aránya a keresők közül (1941),

- a mezőgazdasági keresőkön belül az önálló birtokosok és bérlők aránya (1941),

- a népességszám-változás rátája (1910-1941;1910=100\%),

- az egy főre jutó lakóházak rátája (laksűrűség) (1941). 
A sokdimenziós jelleg miatt az egyedi mutatószámok standardizálás után váltak összevonhatóvá, amely során minden mutatót azonos súllyal vettem számításba. ${ }^{4} \mathrm{~A}$ fenti mutatószámok a vizsgált területről statikus, kimerevített „,pillanatfelvételek" rekonstruálására alkalmasak, tanulmányomban azonban szeretném az adatfelvételek között eltelt időszak folyamatait és a mögöttük húzódó mechanizmusok szerepét is feltárni. Mivel az elemzett időszakban a Csehszlovákiához került településeken a magyarországitól volumenében és céljaiban is jelentősen eltérő földosztás zajlott, továbbá a csehszlovák állam a térség nemzetiségi összetételét is próbálta telepítésekkel módosítani, kiemelt figyelmet szentelek a földbirtokpolitika és a nemzetiségpolitika hatásainak. Ezeknek a változásoknak a fejlettségre gyakorolt hatását a települési adatsorok összehasonlításával végzem el. ${ }^{5}$

Fontos leszögezni, hogy az általam alkalmazott mutatószámok a fejlettség egy lehetséges értelmezését tükrözik. A kvantitatív módszerek, különösen a komplex mutatók alkalmazásakor és az eredmények értékelésekor szem előtt kell tartani a módszer korlátait. Amint arra a földrajztudományban az 1970-es évektől kibontakozó kritikai irányzatok képviselői is felhívták a figyelmet, a pozitivista, kvantitatív munkák egyik buktatója, hogy a mutatószámok kiválasztása önkényes, és minden esetben a kutató prekoncepciói, szubjektív értéktársításai alakítják (Kitchin 2006). Ezt azért lényeges leszögezni, mert egy ilyen jellegű vizsgálatnál a mutatókat alkotó komponensek torzító hatásai nem kiküszöbölhetők, vagyis akár egyetlen komponens kicserélése valamely más mutatóra könnyedén módosíthatja a „fejlettség” területi képét. Jelen tanulmányban a HDI mintájára kialakított mérőszámaim összetételének meghatározásakor nagy hangsúlyt fektettem a korábbi, hasonló módszeren nyugvó tanulmányok tanulságaira, ugyanakkor a birtokviszonyok beemelése a fejlettségi szempontok közé (elsősorban a mezőgazdasági keresőkön belül az önálló birtokosok és bérlők arányának hangsúlyozása) a korábbi munkákhoz képest újdonságnak tekinthető. A nagybirtok súlyának a helyi társadalom életszínvonalára gyakorolt hatásaira, vagyis a komplex mutatószám birtokviszonyokra vonatkozó elemének relevanciájára a következő oldalakon reflektálok.

\section{Esztergom és Komárom vármegyék fejlettsége a 20. század elején}

A 20. század eleji országterület fejlettségi különbségeinek mérésére a közelmúltban több szerző is vállalkozott. A kvantitatív vizsgálatok tanulsága szerint a Duna Budapest és Bécs közötti szakaszát övező területek 1910-ben dinamikus mutatókkal voltak jellemezhetők (Demeter 2018), így a vármegyei léptékű fejlettségi rangsorban Esztergom és Komárom is a rangsor felső harmadában, annak is az első felében foglalt helyet (Szilágyi 2018b). Beluszky (2000) vármegyei szintü elemzése alapján az általam vizsgált terület ,a nyugat-magyarországi modernizációs ék" része volt a századforduló után. Ugyanakkor települési léptéken vizsgá- 
lódva már a vármegyéken belüli területi differenciák is kirajzolódnak: Pénzes János (2018) területi fejlettségi indexe alapján 1910-ben úgy Esztergom, mint Komárom vármegyék települései között az akkori országterület települési rangsorának felső és alsó tizedébe sorolható település egyaránt megtalálható volt.

A történeti országterület 20. század eleji fejlettségi különbségeit a mezőgazdaság szempontjából vizsgáló Nagy Mariann (2003) Komárom vármegyét a középdunántúli, Esztergom vármegyét a Duna-Tisza közi agrárrégióhoz sorolta. Az általa elvégzett klaszteranalízis tanulsága szerint Komárom vármegye négy másik vármegyével (Fejér, Győr, Somogy és Veszprém) mutatott hasonlóságot. A KözépDunántúl Nagy (2003) elemzése szerint a második legfejlettebb agrárrégiónak volt tekinthető, a legtöbb mutatóban csak Északnyugat-Dunántúl (Moson és Sopron vármegyék) előzte meg. A közép-dunántúli agrárrégióra a nagybirtok dominanciája, és a birtokokon folyó magas jövedelmezőségű állattartás volt jellemző, a nagybirtok jelenlétéhez kapcsolódóan a bérmunka és a gépesítettség is nagyobb arányú volt.

A birtokviszonyok fejlettségre gyakorolt hatásairól a huszadik század első felében több statisztikai szemléletű tanulmány is napvilágot látott. A két világháború között a hazai szakirodalomban megjelent tanulmányok közül kiemelhető Móricz Miklós (1936) elemzése, aki a nagybirtok területi elhelyezkedését a népsürűséggel vetette egybe. Móricz amellett érvelt, hogy a kis- és középbirtokos parasztság által dominált tájakon a nagybirtokos vidékekhez képest magasabb népsűrűség alakult ki, amelyet a nagybirtok alacsony népességeltartó erejének következményeként értékelt.

Vele szemben Lipták László (1937) számos módszertani aggályt fogalmazott meg, amelyek alapján a nagybirtok kifejezetten magasabb gazdasági erejére, népességeltartó képességére következtetett. Lipták szerint a földkoncentráció javára írható, hogy az egyrészt magasabb termésátlagokat eredményezett, másrészt a nagybirtokon élők és dolgozók (a gazdasági cselédek és mezőgazdasági munkások) körében magasabb volt a gyerekszám, mint a birtokos paraszti családokban. Ugyanakkor arra is felhívta a figyelmet, hogy a nyári idénymunkák idején, a nagybirtokon dolgozók (a szezonális munkára érkező summások) jelentős része nem a nagybirtokos vidékeken élt. Ennek következtében a népszámlálásokból kiolvasható népsűrűség alapján nem lehet az egyes vidékek népességeltartó erejére következtetni. Emellett a foglalkozási statisztikák önbevallásos rögzítése Lipták érvelése szerint a magasabb presztízsű munkák irányába torzított, és egyben a nagybirtokon dolgozó idénymunkások népszámlálásokban feltüntetett számát csökkentette: a mezőgazdasági idénymunkákból élők gyakran vettek részt infrastrukturális beruházásokban (sokan dolgoztak közülük például vasútépítéseken) is, amelyet a népszámláláskor szívesebben adtak meg foglalkozásként.

Ennek a vitának (amelynek eldöntése későbbi, nagyobb földrajzi területre fókuszáló vizsgálatok tárgyát képezheti) jelen tanulmány szempontjából a legfontosabb tanulsága, hogy a birtokszerkezet területi különbségei a társadalom 
számos más jellemzőjére is jól kimutatható hatást gyakoroltak. Emiatt az alábbiakban Komárom és Esztergom vármegyék 1910-es, települési léptékü fejlettségi képét a birtokviszonyokkal is egybe kívánom vetni. Ennek egyik eszköze, hogy a fejlettség komplex mutatójának részét képezi a mezőgazdasági keresők közül az önálló birtokosok és bérlők aránya, a másik eszköze pedig, hogy ennek az arányszámnak a területi képét külön térképen is ábrázolom (1. ábra). Elmondható, hogy a vizsgált településeken 1910-ben átlagosan 32,4\% volt az önálló birtokosok és bérlők aránya. A legmagasabb, 50\% feletti és a legalacsonyabb, $15 \%$ vagy az alatti értékkel egyaránt nyolc település volt jellemezhetö. A legtöbb településen a mezőgazdasági keresők 35,1\%-50\%-a volt önálló birtokos vagy bérlő, ezeknek a településeknek a zöme a vizsgált terület déli, dombvidéki tájain helyezkedett el. A $25 \%$ vagy az alatti, de $15 \%$ feletti arányszámmal jellemezhetö települések többsége ugyanakkor a Duna bal partján feküdt.

A területi fejlettség komplex mutatója alapján kirajzolódó különbségeket kétféle módszerrel térképeztem. A 2. ábra, illetve a következő szekcióban található 5. ábra az egyenlő intervallumok elve alapján készült, vagyis a komplex mutató legnagyobb és legkisebb érteke között négy darab, egymástól egyenlő távolságra lévő szakaszhatár került elhelyezésre. Így a 2. és 5. ábra alapján az egyes települések közötti fejlettségi különbségek mértékét tudjuk azonosítani. A második ábrázolási módszer a kvantilisek módszere (3. és 6. ábra). Ennek során a tele-

1. ábra: Az önálló birtokosok és bérlők aránya a mezőgazdasági keresők közül a vizsgált területen (1910)

Percentage of owners and leaseholders within the agricultural workforce (1910)

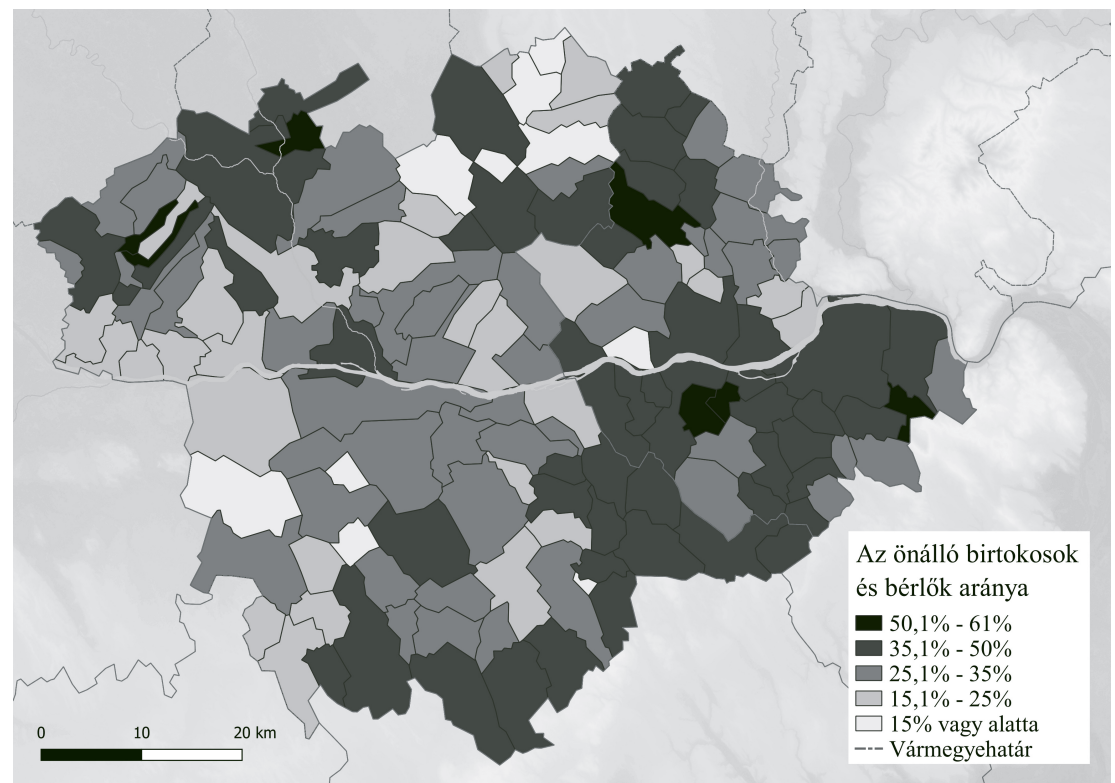

Forrás: KSH (1913) alapján saját szerkesztés 
pülések fejlettségi rangsorát öt, egyenlő elemszámú részre osztottam. Ez a módszer megmutatja, hogy az egyes települések egymáshoz képest milyen pozícióval jellemezhetők, így inkább alkalmas a fejlettségi sorrend időbeli átrendeződésének bemutatására, mint az egyenlő intervallumok módszere. Az előző módszernél kirajzolódó kisszámú magasan fejlett és nagyszámú átlag alatti, vagy mélyen átlag alatti település helyett a kvantiliseket ábrázoló térképeken minden kategóriában ugyanannyi település van, azaz ezzel a módszerrel „kisimíthatók” a kiugró fejlettségi értékek.

Esztergom és Komárom vármegyék területén 1910-ben két településtípus tekinthető magasan fejlettnek: a városok (a vármegyék központjai, illetve az uradalmi központ Tata) mellett a Gerecse környezetében található bányásztelepülések mutatnak jóval átlag feletti értékeket (2. ábra). E települések legmarkánsabb közös jegye a mezőgazdasági keresők alacsony aránya (bár Tatán ez az érték némileg magasabb). Emellett az orvosi kezelésben részesült elhunytak és a jó minőségű lakóházak aránya is rendre magasabb értékeket mutat ezeken a településeken. A foglalkoztatottak szektorális megoszlásának tekintetében kilóg a sorból Baj község, ahol a mezőgazdasági keresők aránya 74\% körül alakult: a falu magas fejlettségi mutatóját a jó minőségű lakóházak nagyon magas aránya generálta. A legfejlettebb kategóriához hasonló módon kisszámú település került az átlag feletti csoportba. Ezek olyan települések, ahol ugyancsak alacsony mezőgazdasági

2. ábra: Esztergom és Komárom vármegyék településeinek fejlettségi különbségei (1910)

Territorial development disparities in Esztergom and Komárom counties (1910)

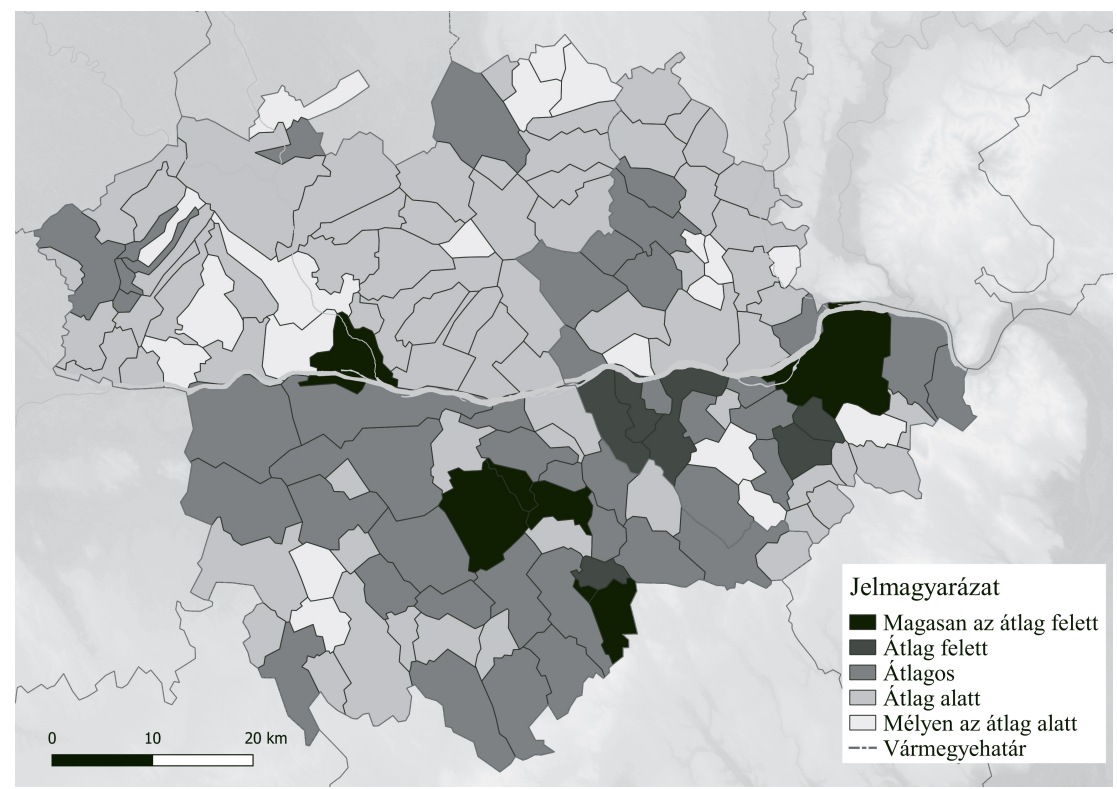

Forrás: KSH $(1912,1913)$ alapján saját számítás 
foglalkoztatottság volt jellemző, hiszen zömmel a Gerecse északi lábánál, valamint a Dorogi-medencében található bányászfalvak tartoztak ide.

Jóval nagyobb volt az átlagos fejlettségü települések köre. Ezek zömmel a Duna jobb partján található települések voltak, amelyek között a nem mezőgazdasági keresők által dominált dombvidéki falvak mellett már számos, mezőgazdasági keresők által lakott falu is található. A Duna bal partján található átlagos fejlettségü települések egyrészt Esztergom vármegye északnyugati határán, másrészt a Csallóközben feküdtek, és lakói főleg őstermelők voltak. A mezőgazdasági településekkel kapcsolatban a Duna mindkét partjára érvényes, hogy közülük azok kerültek az átlagosan fejlett kategóriába, ahol magas volt az orvosi kezelésben részesült elhunytak aránya.

A legtöbb település átlag alatti fejlettséggel volt jellemezhető, és ezek többsége a vármegyék északi felében helyezkedett el. A fejlettségi mutató komponensei alapján két jellegzetes csoportjuk azonosítható: egy részükben a mezőgazdasági keresőkön belül nagyon alacsony volt az önálló birtokosok és bérlők aránya, vagyis a nagybirtok dominanciája miatt a cselédség és a mezögazdasági munkásság jelentős súlyt képviselt. Ezek a települések Komárom vármegye déli részén, továbbá a Csallóköz délkeleti területein, valamint Komárom vármegye északkeleti szegletében alkottak összefüggő területet. Az átlag alatti fejlettségű települések másik csoportjában az önálló birtokosok és bérlők aránya magasabb volt, a haláluk előtt orvosi kezelésben részesült elhunytak aránya azonban rendre az átlagosnál jóval alacsonyabban alakult. A legalacsonyabb komplex mutatóval rendelkező településeken a cselédek és mezőgazdasági munkások nagy aránya mellett főként a népesség alacsony műveltségi szintje volt jellemző, ugyanis a mélyen átlag alatti településeken volt a legkisebb az írni és olvasni tudók aránya.

Az előzőekben bemutatott területi fejlettségi struktúrát nagyjából leképezi, ugyanakkor a különbségeket még karakteresebben jeleníti meg a településeket kvantilisek szerint csoportosító elemzési módszer (3. ábra). Különösen szembetűnő a Duna két partja közötti különbség a települési fejlettség tekintetében. Az 1910-ben felrajzolható térstruktúrát jól leírja, hogy a települési rangsor felső $20 \%$-ába tartozó városok és községek közül mindössze négy található a Duna bal partján (ezek a csallóközi Felsőgellér mellett a vármegyeszékhely Komárom, valamint a járási székhely rangot birtokló Párkány és Udvard), miközben a vármegyék déli részén ugyanez a szám 24 (1. táblázat). A rangsor alsó ötödébe sorolt települések esetén nagyjából ennek fordítottja a helyzet: a Duna bal partjáról 21 község, a Duna jobb partjáról nyolc település került a legalsó ötödbe. A két szélső kategória közötti kvintilisek között jobbára fokozatos az átmenet, hiszen a vizsgált terület déli részén a rangsor eleje felé haladva az egyes ötödökbe tartozó települések száma növekszik, míg a Duna vonalától északra elhelyezkedő területen fokozatosan csökken. 
3. ábra: A települési fejlettségi rangsor területi képe Esztergom és Komárom vármegyékben (1910)

Territorial development disparities in Esztergom and Komárom counties based on quintiles (1910)

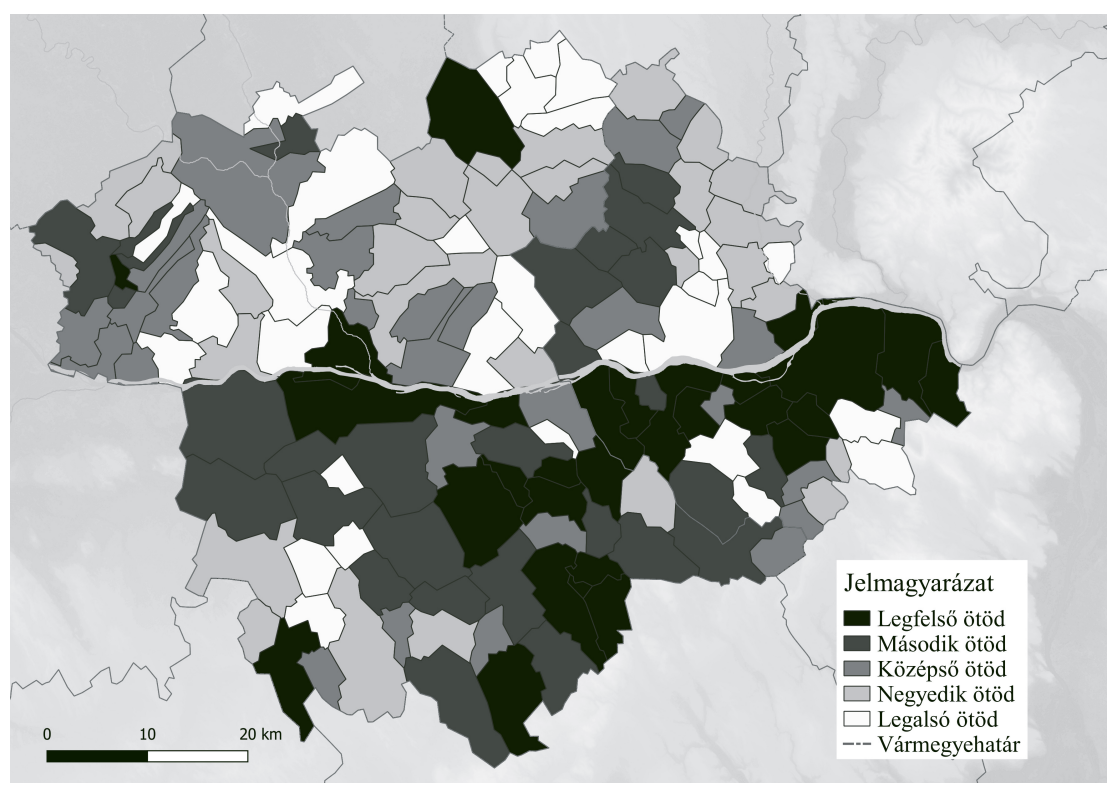

Forrás: KSH $(1912,1913)$ alapján saját számitás

1. táblázat: Az egyes fejlettségi ötödökbe tartozó települések száma járások szerint (1910) Number of settlements by ranking and by district (1910)

\begin{tabular}{|c|c|c|c|c|c|c|}
\hline & & $\begin{array}{c}\text { Legfelső } \\
\text { ötöd }\end{array}$ & $\begin{array}{c}\text { Második } \\
\text { ötöd }\end{array}$ & $\begin{array}{c}\text { Középső } \\
\text { ötöd }\end{array}$ & $\begin{array}{c}\text { Negyedik } \\
\text { ötöd }\end{array}$ & $\begin{array}{c}\text { Legalsó } \\
\text { ötöd }\end{array}$ \\
\hline \multirow{4}{*}{$\begin{array}{l}\text { Duna bal } \\
\text { partja }\end{array}$} & $\begin{array}{l}\text { Csallóközi } \\
\text { járás }\end{array}$ & 2 & 5 & 7 & 5 & 6 \\
\hline & $\begin{array}{c}\text { Párkányi } \\
\text { járás }\end{array}$ & 1 & 6 & 4 & 8 & 6 \\
\hline & $\begin{array}{l}\text { Udvardi } \\
\text { járás }\end{array}$ & 1 & 0 & 6 & 8 & 9 \\
\hline & Összesen & 4 & 11 & 17 & 21 & 21 \\
\hline \multirow{4}{*}{$\begin{array}{l}\text { Duna jobb } \\
\text { partja }\end{array}$} & $\begin{array}{l}\text { Esztergomi } \\
\text { járás }\end{array}$ & 11 & 3 & 4 & 2 & 4 \\
\hline & $\begin{array}{c}\text { Gesztesi } \\
\text { járás }\end{array}$ & 2 & 8 & 2 & 4 & 3 \\
\hline & Tatai járás & 11 & 6 & 5 & 1 & 1 \\
\hline & Összesen & 24 & 17 & 11 & 7 & 8 \\
\hline
\end{tabular}

Forrás: KSH (1912, 1913) alapján saját számítás 


\section{A határváltozások hatásai}

Az 1920-as trianoni döntés értelmében a történeti Esztergom vármegye 25 települése, Komárom vármegye 49 települése az újonnan megalakult Csehszlovákiához került, így ezeken a területeken egészen az 1938-as első bécsi döntésig a csehszlovák állam szándékai alakították a helyi társadalmak körülményeit. Az időszakot a földkérdés megoldása mellett a nemzetiségi viszonyok radikális átalakításának szándéka fémjelezte. A csehszlovák kormányzat két világháború közötti politikájában kiemelt szerepet betöltő földosztás és a nemzetiségi arányok megváltoztatása szorosan összefonódott, mivel a cseh területeken a németek, a Szlovákiához sorolható területeken pedig a magyarok képezték a nagybirtokos elit gerincét (Bartha 2012; Miller 2003).

A földosztás végrehajtása során ennek következtében a kiemelt szempont az volt, hogy a nagybirtokok helyén cseh, illetve szlovák kis- és középbirtokok alakuljanak ki. Ennek a folyamatnak a mérlegéről elmondható, hogy a dél-szlovákiai magyarságot több szempontból is negatívan érintette. Az első bécsi döntéssel visszacsatolt felvidéki területsávon az első világháború előtt szinte kizárólag magyar nemzetiségűek által birtokolt földterületek túlnyomó része helyi szlovákok (a kiosztott földek 25\%-a), illetve szlovák és cseh, valamint morva nemzetiségü telepesek (a kiosztott földek 18,2\%-a) kezébe került. Mindeközben a helyi magyarság a kiosztott földterületnek mindössze 19\%-át kapta. A földosztásnak az életszínvonalra gyakorolt hatásait illetően fontos megjegyezni, hogy a legrosszabbul a nagybirtokon dolgozó magyar nemzetiségü emberek jártak. Az egykori cselédek és mezőgazdasági munkások zöme nem válhatott újgazdává, miközben korábbi munkalehetőségük (a nagybirtok) is megszűnt. Mindemellett a helyi magyarok az anyaországi lakhellyel rendelkező, de a Felvidéken földeket birtokló emberekkel szemben is hátrányba kerültek, ugyanis a külföldi lakhellyel rendelkezők birtokait (a trianoni döntés vonatkozó részei alapján) csak kis részben érintette a csehszlovák földosztás (Simon 2009, 2014).

A csehszlovák nemzetiségi és földbirtokpolitika egyik sarokpontját képezték az 1922 és 1929 között zajlott telepítések, amelyek a településhálózatban is változásokat generáltak. Esztergom és Komárom vármegyék Duna bal partján található területein 18 telepes község alakult. Ezek egy része az első bécsi döntést követő hetekben ugyan elnéptelenedett, azonban az 1938-as felvidéki nép-, földbirtokés állatösszeírás idején néhány telep még lakott volt (Simon 2009, 2014), így az összeírásban a telepes falvak adatai külön is szerepelnek. Az összevethetőséget segíti ugyanakkor, hogy a felmérést végzők a kolóniák adatait azokkal a falvakéval is összevonták, amelyekhez Trianon előtt közigazgatásilag tartoztak, így az egyszerüség kedvéért tanulmányomban az összevont adatokkal dolgozom, ${ }^{6}$ azaz az 1910-es közigazgatási beosztást veszem alapul. ${ }^{7}$

Mivel a csehszlovák földosztás magyar állam általi revíziója csak 1938 végétől indult meg és több éven keresztül zajlott (Simon 2014; Tilkovszky 1964), az itt 
elemzett, 1938. decemberi felvidéki nép-, földbirtok- és állatösszeírás idején javarészt a csehszlovák időszak alatt kialakult földbirtokviszonyok kerültek rögzítésre. Ugyanakkor a nemzetiségi összetételben bekövetkezett változások (amelyek főleg a már említett kolonizáció révén zajlottak) kevésbé mutathatók ki, mivel az adatfelvétel idejére a telepesek zöme elmenekült (Konkoly Thege 1939; Thirring 1939). Az összeírás értékelését végző statisztikusok a birtokviszonyok elemzése kapcsán a visszacsatolt területsávon a nagybirtok jelentőségének csökkenésére, a középbirtok súlyának növekedésére hívták fel a figyelmet. Ugyanakkor jól kimutatható területi különbségeket is azonosítottak, amely kapcsán kiemelendő, hogy Komárom környékén relatíve nagy volt a $3000 \mathrm{kh}$ feletti birtoktestek által elfoglalt terület (Szőllősy 1939). Mindemellett a törpebirtokok száma - a magyarországi földreformhoz hasonlóan a Felvidéken is - jelentősen növekedett a reform hatására, amely nem javított az érintett népesség szociális helyzetén (A Magyar Statisztikai Társaság Államtudományi Intézete 1938).8

Mindeközben az 1920-as magyarországi földreform alig változtatott a korábban kialakult földbirtokstruktúrán. A földreform ugyan sok új birtokost eredményezett, ők azonban javarészt a törpebirtokossághoz tartoztak, aminek következtében a reform érdemben nem csökkentette a nagybirtokok súlyát. A két világháború közötti időszakban a trianoni országterületen az összes földterület egyharmada (a szántóterület 20\%-a) 1000 kataszteri hold feletti nagybirtokok kezében összpontosult (Szuhay 1998). Az általam vizsgált terület Dunától délre eső részén szintén kiemelkedő maradt a nagybirtok súlya: itt 1928 és 1930 között a mezőgazdasági terület 46\%-át foglalták el 500 holdas, vagy annál nagyobb földbirtokok. ${ }^{9}$

Az önálló mezőgazdasági keresők aránya ugyanakkor 1910-hez viszonyítva a Duna bal és jobb partján egyaránt növekedett, és 1938/1941-ben átlagosan 39\% volt a vizsgált településeken. A mutató értéke mindössze két településen volt 15\% vagy az alatti, és csak hat településen vett fel 15,1\% és 25\% közötti értéket (4. ábra). Erőteljesen növekedett a 35,1-50\% közötti értékkel jellemezhető települések száma, valamint a mezőgazdasági önállók $50 \%$ feletti aránya is jóval több településen volt megfigyelhető 1938/1941-ben, mint három évtizeddel korábban. Fontos látni, hogy a felső kategóriába tartozó települések zöme a Duna bal partján helyezkedett el: a Duna jobb partján két, míg a bal parton 13 település sorolható ide. Ugyanakkor a 35,1\% és 50\% közötti mutatóval bíró települések területi elhelyezkedése kiegyensúlyozottabb volt, mivel a Duna bal partján 37, a Duna jobb partján 43 település tartozott ebbe a kategóriába.

A fejlettségi különbségek mértéke az 1930-as évek végére némileg csökkent a vizsgált területen (5. ábra). Magasan az átlag feletti fejlettséggel jellemezhető Dorog, amelynek kiugró fejlettségi mutatója a nem mezőgazdasági keresők magas aránya (1941-ben 94\%) mellett az intenzív népességnövekedésnek tudható be: 1910 és 1941 között Dorog lakosságszáma közel 1950 főről több mint 8100 főre emelkedett. Az átlag feletti fejlettségü községek és városok köre a Duna jobb partján nagyjából megegyezett a Trianon előtt átlag felett, vagy magasan az átlag 
4. ábra: Az önálló birtokosok és bérlők aránya a mezőgazdasági keresők közül a vizsgált területen (1938/1941)

Percentage of owners and leaseholders within agricultural workforce (1938/1941)

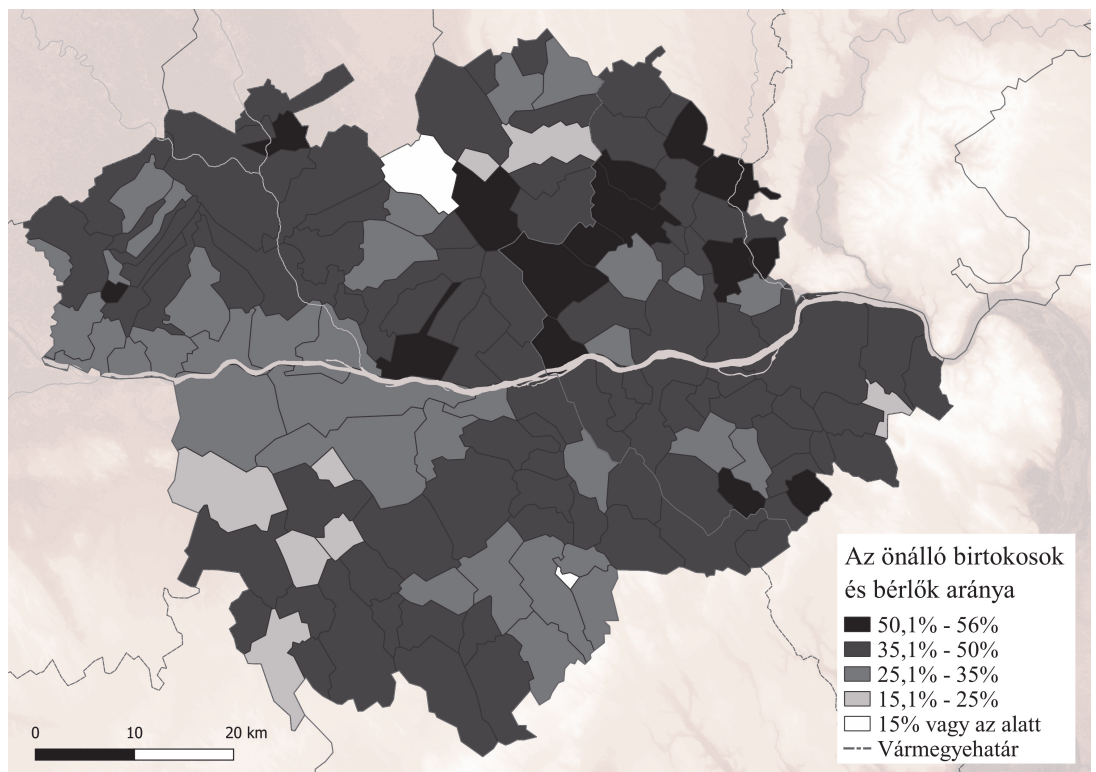

Forrás: KSH $(1939,1975)$ alapján saját szerkesztés

5. ábra: Esztergom és Komárom vármegyék településeinek fejlettségi különbségei (1938/1941) Territorial development disparities in Esztergom and Komárom counties (1938/1941)

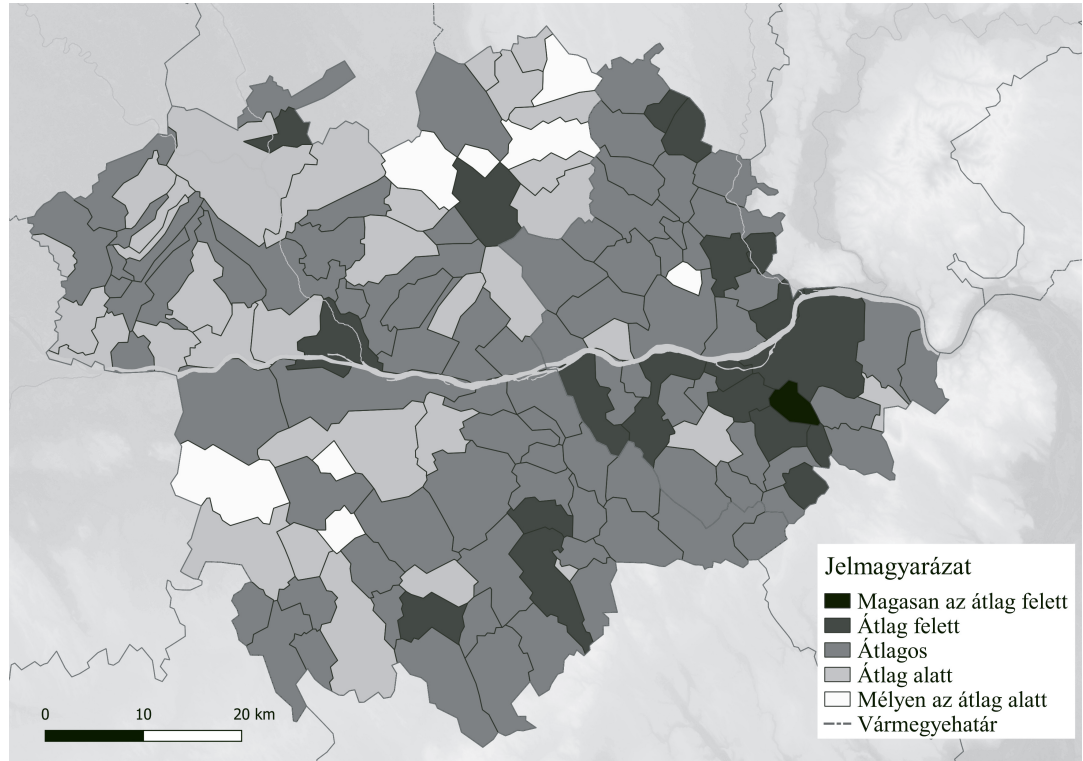

Forrás: KSH (1939, 1975, 1976, 1982) alapján saját számitás 
felett besorolt települések körével. Továbbra is a fejlettebbek között voltak a Gerecse északi és délnyugati előterében, valamint a Dorogi-medencében található, zömmel nem mezőgazdasági keresők által lakott települések. A Duna bal partján ugyanakkor szembetűnő változások zajlottak. Különösen figyelemre méltó, hogy a területen öt olyan község is található, amely 1910-ben még az átlag alatti, vagy mélyen az átlag alatti, 1938-ban azonban már az átlag feletti kategóriába tartozott. Az érintett községek közös jellemzője, hogy a mezőgazdasági önálló népesség mindegyikben 50\% fölé, vagy 50\% környékére növekedett az első bécsi döntés idejére (vö. a 4. ábrával). Ugyanennek a folyamatnak tudható be, hogy a vizsgált terület Duna bal parti felén számos, korábban átlag alatti település 1938-ra átlagos fejlettségünek volt tekinthető.

Az 1938/1941-es fejlettségi rangsort öt egyenlő számú egységre bontva látható, hogy az 1910-ben kirajzolódó észak-dél dualitás az 1930-as évek végére lényegében eltűnt, megjelent azonban a keleti (1910-ben Esztergom vármegyéhez tartozó települések) és a nyugati (1910-ben Komárom vármegyéhez tartozó települések) térségek határozott elkülönülése a fejlettség tekintetében (6. ábra és 2. táblázat). A terület Csehszlovákiához került részén az 1938-as adatok alapján a fejlettségi rangsor mindegyik ötödében nagyjából ugyanannyi település foglalt helyet, ez a kiegyenlítődés azonban szinte kizárólag az Esztergom vármegyéhez sorolható települések előbbre kerülésének köszönhető: az alsó két ötödben to-

6. ábra: A települési fejlettségi rangsor területi képe

Esztergom és Komárom vármegyékben (1938/1941)

Territorial development disparities in Esztergom and Komárom

counties based on quintiles (1938/1941)

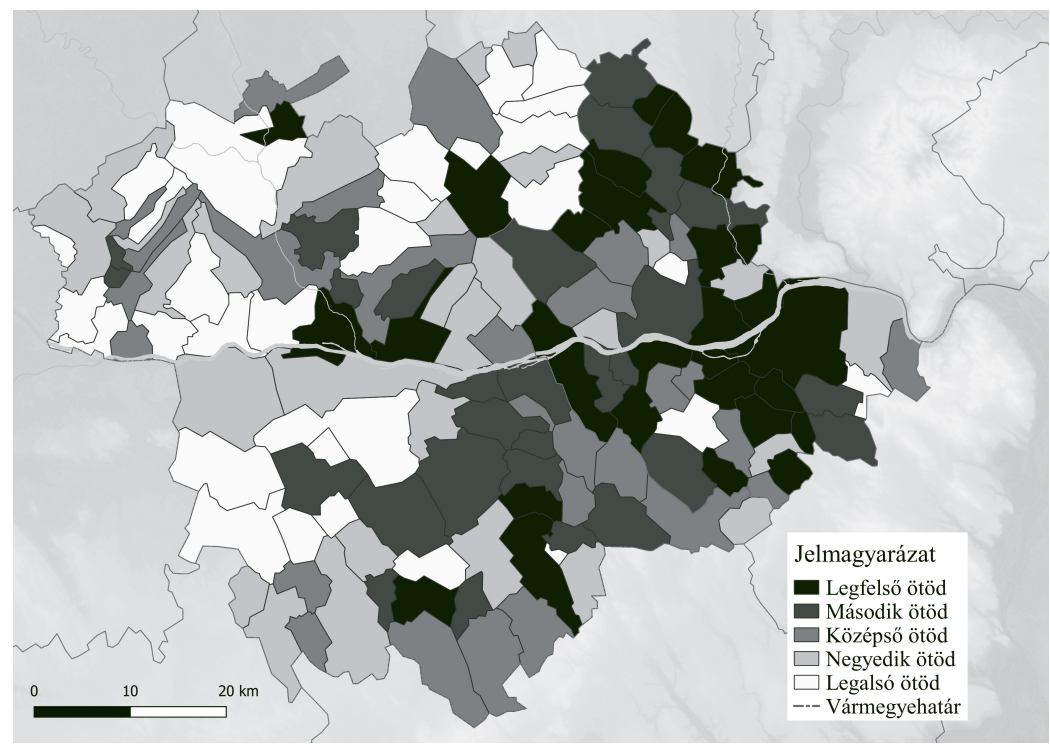

Forrás: KSH (1939; 1975; 1976; 1982) alapján saját számítás 
2. táblázat: Az egyes fejlettségi ötödökbe tartozó települések száma járások szerint (1938/1941) Number of settlements by ranking and by district (1938/1941)

\begin{tabular}{|c|c|c|c|c|c|c|}
\hline & & $\begin{array}{c}\text { Legfelso" } \\
\text { ötöd }\end{array}$ & $\begin{array}{c}\text { Második } \\
\text { ötöd }\end{array}$ & $\begin{array}{c}\text { Középső } \\
\text { ötöd }\end{array}$ & $\begin{array}{c}\text { Negyedik } \\
\text { ötöd }\end{array}$ & $\begin{array}{c}\text { Legalsó } \\
\text { ötöd }\end{array}$ \\
\hline \multirow{4}{*}{$\begin{array}{l}\text { Duna bal } \\
\text { partja }\end{array}$} & $\begin{array}{l}\text { Csallóközi } \\
\text { járás }\end{array}$ & 2 & 2 & 6 & 5 & 10 \\
\hline & $\begin{array}{c}\text { Párkányi } \\
\text { járás }\end{array}$ & 11 & 7 & 3 & 3 & 1 \\
\hline & $\begin{array}{l}\text { Udvardi } \\
\text { járás }\end{array}$ & 2 & 2 & 4 & 8 & 8 \\
\hline & Összesen & 15 & 11 & 13 & 16 & 19 \\
\hline \multirow{4}{*}{$\begin{array}{l}\text { Duna jobb } \\
\text { partja }\end{array}$} & $\begin{array}{c}\text { Esztergomi } \\
\text { járás }\end{array}$ & 10 & 5 & 5 & 2 & 2 \\
\hline & $\begin{array}{c}\text { Gesztesi } \\
\text { járás }\end{array}$ & 1 & 3 & 3 & 6 & 6 \\
\hline & Tatai járás & 2 & 9 & 7 & 4 & 1 \\
\hline & Összesen & 13 & 17 & 15 & 12 & 9 \\
\hline
\end{tabular}

Forrás: KSH (1939, 1975, 1976, 1982) alapján saját számitás

vábbra is jelenős számú község maradt, amelyek a Csallóközben, illetve Komárom vármegye északi, északkeleti területén helyezkedtek el. A Duna jobb partján, Komáromtól délre számos község komolyabb rangsorvesztést szenvedett el. Ez bizonyos települések esetén a rangsor második ötödéből a negyedik, vagy a legalsó ötödbe történő lecsúszást jelentett. Ez a jelenség annak tudható be, hogy amíg számos helyen (főleg a Csehszlovákiához került községekben) növekedett az önálló mezőgazdasági keresők száma, addig ezeken a településeken az első világháború előtt is meghatározó uradalmak fennmaradása miatt nagyon magas volt a cselédek és a mezőgazdasági munkások aránya.

\section{Összegzés}

Tanulmányom rávilágított arra, hogy a két világháború közötti időszakban Esztergom és Komárom vármegyék Csehszlovákiához került településein olyan változások zajlottak, amelyek alapján kevéssé beszélhetünk az egész terület útfüggöségéről, mindeközben nem mutatható ki egyértelműen a Duna bal és jobb partja közötti szétfejlődés sem. A földbirtokviszonyokban bekövetkezett változások jól láthatóan leképeződnek a fejlettség területi mintázatában is. Amíg az első világháború előtt a vármegyék déli részeihez képest (főleg a Gerecse környéki bányászvidékekkel egybevetve) a Duna bal partján fekvő települések rosszabb mutatókkal rendelkeztek, addig a két világháború közötti időszakra ez a kettősség 
némileg oldódott. Ennek oka nagyrészt az önálló birtokosok és bérlők arányának növekedése a csehszlovák földosztás nyomán. Amellett azonban, hogy általában csökkent a fejlettségi különbségek mértéke, a települések fejlettségi sorrendjében kimutatható bizonyos szintű folytonosság. A legfejlettebb térségek (a már említett Gerecse környéke és a városok) mindkét vizsgált időmetszet esetében a rangsor elején helyezkedtek el, miközben a Kelet-Csallóköz és Komárom vármegye északkeleti csücske, valamint déli határvidéke tartósan a negyedik-ötödik ötödbe tartozott. Ennek oka az ipari, bányászati tevékenységek elhelyezkedése (amely a legfejlettebb településeket rajzolja ki) mellett a nagybirtokon dolgozók relatív súlyának fennmaradása (a rangsor alján található települések esetén).

Mivel a kutatás egy viszonylag rövid időszakra, valamint egy kisebb területre fókuszált, a történeti Esztergom és Komárom vármegyék hosszabb távú fejlödési folyamatainak megértéséhez csak adalékként szolgálhat, és semmiképp sem várhatjuk tőle a jelenlegi helyzet pontos megértését. Mindemellett a fejlettségi különbségek történeti gyökerére némi rálátást nyújt, hiszen a második világháború előtt a térség belső fejlettségi különbségeiben kimutatható bizonyos tényezők (elsősorban a foglalkozási szektorok) differenciáló szerepe.

\section{Jegyzetek}

1 Forrás: Magyar Királyi Központi Statisztikai Hivatal (1912): A Magyar Szent Korona országainak 1910. évi népszámlálása. I. rész. (A népesség fóbb adatai.) (Magyar Statisztikai Közlemények. Új sorozat; 42.) Budapest; Magyar Királyi Központi Statisztikai Hivatal (1912): Népmozgalom 1901-1910. (Magyar Statisztikai Közlemények. Új sorozat; 46.) Budapest; Magyar Királyi Központi Statisztikai Hivatal (1913): A Magyar Szent Korona országainak 1910. évi népszámlálása. II. rész. (A népesség foglalkozása és a nagyipari vállalatok községenként.) (Magyar Statisztikai Közlemények. Új sorozat; 48.) Budapest.

2 Forrás: Magyar Királyi Központi Statisztikai Hivatal (1939): Az 1938. évi felvidéki nép-, földbirtok-és állatösszeírás. Az 1938. november 2-i bécsi döntés alapján visszacsatolt területen végrehajtott összeírás eredményei községek szerint. (Magyar Statisztikai Közlemények. Új Sorozat; 108.) Budapest.

3 Forrás: Központi Statisztikai Hivatal Könyvtár és Dokumentációs Szolgálat Magyar Országos Levéltár (1975): Az 1941. évi népszámlálás. 1. Foglalkozási adatok községek szerint. Budapest; Központi Statisztikai Hivatal Könyvtár és Dokumentációs Szolgálat Magyar Országos Levéltár (1976): Az 1941. évi népszámlálás. 2. Demográfiai adatok községek szerint. Budapest; Központi Statisztikai Hivatal Könyvtár és Dokumentációs Szolgálat Magyar Országos Levéltár (1982): Az 1941. évi népszámlálás. 5. Lakóház-és lakásadatok községek szerint. Budapest.

4 A standardizálás során az adatsorok átlagával és szórásával számoltam. Erre, a komplex mutatón alapuló módszerre a Győri-féle módszerként hivatkoztak: Demeter, Szulovszky (2018).

5 Az általam használt 1910-es adatsorok, illetve az 1941-es adatok egy része excel táblázatként elérhető a GISta Hungarorum (OTKA K 111766) projektnek köszönhetően: http://gistory.hu/g/ hu/gistory/otka. Az 1938-as adatfelvételnek a vizsgált vármegyékre vonatkozó táblázatait Vajda Zsófia rögzítette az MTA BTK Lendület Tíz Generáció projekt keretében, amit ezúton is szeretnék megköszönni!

6 A korábban Marcelházához tartozó Szilospuszta 1938-ban Šrobárová néven került feljegyzésre, míg az 1938-ban Hodžovo néven létező kolónia három korábbi pusztára épült rá, amelyek közül az 1910-ben Túriszakállashoz tartozó Zsemlékespuszta képezte az új község magját. 
7 Hasonlóképpen igyekeztem eljárni azokkal a településekkel, amelyek időközben összevonásra, vagy éppen szétválasztásra kerültek: az 1919-ben kettévált Komárom város adatait a déli és az északi részére összevontan kezelem, ugyanakkor az időközben összevont Tatabánya adatait külön, az 1910-es beosztás alapján rögzítem. Egyetlen esetben voltam kénytelen ettől a módszertől eltérni, mivel a Tatához csatolt Tóváros adatait 1941-re nem lehetséges leválasztani, így Tóváros Tatával egybevontan szerepel.

8 Ezek a folyamatok rámutatnak az általam használt komplex mutató korlátaira is, hiszen az önálló birtokosok és bérlők arányának növekedése sok helyen a kis birtokkategóriák térnyerésével járt 1920 után. A törpebirtokosság és az uradalmi cselédség jövedelmi viszonyainak összevetése (Gunst 1998) alapján pedig sokszor a nagybirtokokon élők jövedelmének értéke magasabb volt, mint a néhány holdas parasztságé. Mindezek mellett úgy gondolom, hogy az életszínvonal egyéb aspektusai (például az iskolalátogatás nehézsége, a lakhatás alacsony színvonala: Illyés 2003 [1936]; a társadalmi mobilitás alacsony szintje: Eperjessy 2006) tekintetében már kevésbé egyértelmű a cselédség jobb helyzete, valamint a cselédek és mezőgazdasági munkások erős és összetett függése alapján is a néhány holdas önállók felé billen a mérleg.

\section{Köszönetnyilvánítás}

A tanulmány az Innovációs és Technológiai Minisztérium ÚNKP-20-4 kódszámú Új Nemzeti Kiválóság Programjának a Nemzeti Kutatási, Fejlesztési és Innovációs Alapból finanszírozott szakmai támogatásával, az MTA BTK Lendület Tíz Generáció Kutatócsoport területi egyenlőtlenség munkacsoportjában készült.

\section{Irodalom}

A Magyar Statisztikai Társaság Államtudományi Intézete (1938): A felvidéki magyarság húsz éve 1918-1938. Budapest

Bartha Á. (2012): A két világháború közti csehszlovák, jugoszláv és román földbirtokrendezés. Valóság, 10., 96-112.

Beluszky P. (2000): Egy fél siker hét stációja: avagy a modernizáció regionális különbségei a századelő Magyarországán. In: Dövényi Z. (szerk.): Alföld és nagyvilág. Tanulmányok Tóth Józsefnek. MTA Földrajztudományi Kutatóintézet, Budapest, 299-326.

Berry, B. J. L. (1964). Aproaches to regional analysis: A synthesis. Annals of the Association of American Geographers 1., 2-11. https://doi.org/10.1111/j.1467-8306.1964.tb00469.x

Demeter G. (2018): Perifériák és fejlett régiók a történeti Magyarországon (1890-1910). In: Demeter G., Szulovszky J. (szerk.): Területi egyenlőtlenségek nyomában a történeti Magyarországon: Módszerek és megközelítések. MTA BTK, DE TTT, Budapest - Debrecen, 145-194.

Demeter G. (2019): Az 1938-1941 között visszatért területek fejlettsége és szerepe az anyaország és az utódállamok gazdaságában a különféle történeti narratívák tükrében. Pro minoritate, ősz, 35-68.

Demeter G., Szulovszky J. (szerk.) (2018): Területi egyenlőtlenségek nyomában a történeti Magyarországon: Módszerek és megközelitések. MTA BTK, DE TTT, Budapest - Debrecen

Eperjessy E. (2006): Puszták népe a Zselicben (1900-1950). Mikszáth Kiadó, Horpács

Gaucsík I. (2004): A csehszlovákiai magyarság gazdasági szervezetei (1918-1938): Gazdasági egyesületek, szövetkezetek, ipartársulatok. Korall: Társadalomtörténeti Folyóirat 18., 48-64.

Gunst P. (1998): A magyar agrártársadalom 1919-1945 között. In: Gunst P. (szerk): A Magyar agrártársadalom a jobbágyság felszabaditásától napjainkig. Napvilág Kiadó, Budapest, 231-284.

Győri R., Jankó F. (2009): Nyugat-Dunántúl és Burgenland regionális fejlettségi különbségeinek alakulása 1910 és 2001 között. Soproni Szemle, 2., 218-238. 
Győri R., Mikle Gy. (2017): A fejlettség területi különbségeinek változása Magyarországon, 1910-2011. Tér és Társadalom, 3., 143-165. https://doi.org/10.17649/TET.31.3.2866

Haltenberger I. (2002): A parasztság. In: Borsody I. (szerk.): Magyarok Csehszlovákiában. Méry Ratio, Somorja, 148-155.

Hantos L. (2002): Gazdasági életünk húsz éve. In: Borsody I. (szerk.): Magyarok Csehszlovákiában. Méry Ratio, Somorja, 77-88.

Heffernan, M. (2009): Historical geography. In: Gregory, D., Johnston, R., Pratt, G., Watts, M., Whatmore, S. (eds.): Dictionary of human geography. Blackwell, Oxford, 332-335.

Illyés Gy. (2003 [1936]): Puszták népe. Századvég, Budapest

Jaschitz M. (2010): Elzárt múlt-határtalan jövő? Esztergom vonzáskörzete a huszadik században és az ezredfordulón. Tér és Társadalom, 3., 93-118. https://doi.org/10.17649/TET.24.3.1330

Jeney L., Varga Á. (2016): A felzárkóztatás eredményei és kudarcai az Encsi járásban. Területi Statisztika, 2., 183-208. https://doi.org/10.15196/TS560205

Kitchin, R. (2006): Positivistic geographies and spatial science. In: Aitken, S., Valentine, G. (eds.): Approaches to human geography. Sage, London, Thousand Oaks, New Delhi, 20-29.

Konkoly Thege Gy. (1939): Az 1938. évi felvidéki nép-, földbirtok- és állatösszeírás. Magyar Statisztikai Szemle, 5., 447-453.

Kovách I. (2012): Vidék az ezredfordulón. A jelenkori magyar vidéki társadalom szervezeti és hatalmi változásai. Argumentum Kiadó, Budapest

Kovács Z. (1990): A határ menti területek központhálózatának átalakulása az első világháború utántól napjainkig. Földrajzi Közlemények, 114., 3-16.

Lipták L. (1937): A mezőgazdaság népességeltartó erejének statisztikai vizsgálata különös tekintettel a birtokmegoszlásra. Magyar Statisztikai Szemle, 7., 612-621.

Malatyinszky Sz. (2010): A települések emberi erőforrásának mérése. Földrajzi Közlemények, 1., 45-59.

Miller, D. E. (2003): Colonizing the Hungarian and German Border Areas During the Czechoslovak Land Reform, 1918-1938. Austrian History Yearbook, 34., 303-317.

Móricz M. (1936): Nagybirtok, népszaporodás, népsűrűség. Magyar Statisztikai Szemle, 4., 293-309.

Nagy M. (2003): A magyar mezögazdaság regionális szerkezete a 20. század elején. Gondolat, Budapest

Nemes Nagy J. (szerk.) (2005): Regionális elemzési módszerek. ELTE Regionális Földrajzi Tanszék, Budapest (Regionális Tudományi Tanulmányok, 11.)

Offen, K. (2013): Historical geography II: Digital imaginations. Progress in Human Geography, 4., 564-577. https://doi.org/10.1177/0309132512462807

Pénzes J. (2018): Fejlettségi különbségek és centrum-periféria viszonyok a történelmi Magyarországon. Összehasonlító módszertani vizsgálat. In: Demeter G., Szulovszky J. (szerk.): Területi egyenlötlenségek nyomában a történeti Magyarországon: Módszerek és megközelitések. MTA BTK Történettudományi Intézet, Budapest, 85-116.

Pénzes, J. (2020): The impact of the Trianon Peace Treaty on the border zones - an attempt to analyse the historic territorial development pattern and its changes in Hungary. Regional Statistics, 1., 60-81. https://doi.org/10.15196/RS100102

Pénzes, J., Demeter, G. (2021): Peripheral areas and their distinctive characteristics: The case of Hungary. Moravian Geographical Reports, 3., 217-230. https://doi.org/10.2478/mgr-2021-0016

Simon A. (2009): Telepesek és telepes falvak Dél-Szlovákiában a két világháború között. Fórum Kisebbségkutató Intézet, Somorja

Simon A. (2014): Magyar idók a Felvidéken (1938-1945). Az első bécsi döntés és következményei. Jaffa Kiadó, Budapest

Szilágyi Zs. (2018a): Az életminőség területi különbségeinek változása Magyarországon a 20. század első harmadában. In: Demeter G., Szulovszky J. (szerk.): Területi egyenlőtlenségek nyomában a történeti Magyarországon: Módszerek és megközelitések. MTA BTK Történettudományi Intézet, Budapest, 255-334.

Szilágyi Zs. (2018b): A Kárpát-medence fejlettségi membránja 1910-ben: A fogalomalkotás és a vizualizálás egy lehetséges módszertani megoldása, az eredmények kontextualizálási kísérlete. In: Demeter G., Szulovszky J. (szerk.): Területi egyenlötlenségek nyomában a történeti Magyarországon: Módszerek és megközelitések. MTA BTK Történettudományi Intézet, Budapest, 47-84. 
Szőllősy Z. (1939): A földbirtokviszonyok a Felvidék visszacsatolt részén. Magyar Statisztikai Szemle, 5., 500-509.

Szuhay M. (1998): A magyar mezőgazdaság a két világháború között. In. Gunst P. (szerk): A Magyar agrártársadalom a jobbágyság felszabadításától napjainkig. Napvilág Kiadó, Budapest, 209-230.

Thirring L. (1939): A népesség a Felvidék visszacsatolt részén. Magyar Statisztikai Szemle, 5., 454-499.

Tilkovszky L. (1964): A csehszlovák földreform magyar revíziója. Agrártörténeti Szemle (Historia rerum rusticarum), 1-2., 113-142.

Tomka B. (2018): Az első világháború és a trianoni béke gazdasági hatásai Magyarországon. In: Bódy Zs. (szerk.): Háborúból békébe: a magyar társadalom 1918 után. Konfliktusok, kihivások, változások a háború és az összeomlás nyomán. MTA Bölcsészettudományi Kutatóközpont Történettudományi Intézet, Budapest, 47-80.

Woods, M. (2005): Rural geography: Processes, responses and experiences in rural restructuring. Sage, London, Thousand Oaks, New Delhi

Woods, M. (2009): Rural geography. In: Kitchin, R., Thrift, N. (eds.): International encyclopedia of human geography. Elsevier, Amsterdam, Oxford, 429-441. 